\title{
Implication of ARID1A Undercurrents and PDL1, TP53 Overexpression in Advanced Gastric Cancer
}

\author{
Jasiya Qadir ${ }^{1}$, Sabhiya Majid ${ }^{1 * t}$, Mosin Saleem Khan ${ }^{1 \dagger}$, Fouzia Rashid ${ }^{2}$, Mumtaz Din Wani ${ }^{3}$ \\ and Showkat Ahmad Bhat ${ }^{4}$
}

${ }^{1}$ Department of Biochemistry, Government Medical College Srinagar and Associated Hospitals, Srinagar, India, ${ }^{2}$ Department of Clinical Biochemistry, University of Kashmir, Srinagar, India, ${ }^{3}$ Department of Surgery, Government Medical College Srinagar and Associated Hospitals, Srinagar, India, ${ }^{4}$ Department of Biochemistry, Government Medical College, Doda, India

OPEN ACCESS

Edited by:

József Tímár,

Semmelweis University, Hungary

${ }^{*}$ Correspondence:

Sabhiya Majid

sabuumajid@gmail.com orcid.org/0000-0002-3678-3313

${ }^{+}$These authors have contributed equally to this work

Received: 29 March 2021 Accepted: 17 November 2021 Published: 03 December 2021

Citation:

Qadir J, Majid S, Khan MS, Rashid F. Wani MD and Bhat SA (2021) Implication of ARID1A Undercurrents and PDL1, TP53 Overexpression in

Advanced Gastric Cancer. Pathol. Oncol. Res. 27:1609826. doi: 10.3389/pore.2021.1609826
AT-rich interactive domain-containing protein 1A (ARID1A), TP53 and programmed cell deathligand 1 (PDL1) are involved in several protein interactions that regulate the expression of various cancer-related genes involved in the progression of the cell cycle, cell proliferation, DNA repair, and apoptosis. In addition, gene expression analysis identified some common downstream targets of ARID1A and TP53. It has been established that tumors formed by ARID1A-deficient cancer cells exhibited elevated PDL1 expression. However, the aberrations in these molecules have not been studied in this population especially in Gastric Cancer (GC). In this backdrop we aimed to investigate the role of the ARID1A mutation and expression of ARID1A, TP53 and PDL1 genes in the etiopathogenesis of Gastric Cancer (GC) in the ethnic Kashmiri population (North India). The study included 103 histologically confirmed GC cases. The mutations, if any, in exon-9 of $A R I D 1 A$ gene was analysed by Polymerase Chain Reaction (PCR) followed by Sanger sequencing. The mRNA expression of the ARID1A, TP53 and PDL1 genes was analysed by Quantitative real time-PCR (qRT-PCR). We identified a nonsense mutation (c.3219; C > T) in exon-9 among two GC patients ( 2.0\%), which introduces a premature stop codon at protein position 1073. The mRNA expression of the ARID1A, TP53 and PDL1 gene was significantly reduced in $25.3 \%$ and elevated in 47.6 and $39.8 \%$ of GC cases respectively with a mean fold change of $0.63,2.93$ and 2.43 . The data revealed that reduced mRNA expression of $A R I D 1 A$ and elevated mRNA expression of TP53 and PDL 1 was significantly associated with the high-grade and advanced stage of cancer. Our study proposes that ARAD1A under-expression and overexpression of TP53 and PDL1 might be crucial for tumor progression with TP53 and PDL1 acting synergistically.

Keywords: gastric cancer, ARID1A, mutation, mRNA expression 3, mRNA expression, qRT-PCR, TP53, PDL1

\section{INTRODUCTION}

Gastric cancer (GC) is prevalent and account for a large number of cancer deaths globally. Although there are considerable advances in cancer diagnosis and therapy, GC remains an important cancer worldwide and is responsible for over one million new cases in 2020 and an estimated 769,000 deaths, ranking fifth for incidence and fourth for mortality globally [1]. In Kashmir valley (North India), GC has been reported as the most frequently diagnosed cancer with an occurrence of around $18.8 \%$ among all cancer cases [2].

Multiple genetic and epigenetic alterations in oncogenes and tumor suppressor genes are involved in the process of gastric carcinogenesis [3]. The ARID1A gene encodes a component of the switch/sucrose 
non-fermentable (SWI-SNF) chromatin remodelling complex [4]. ARID1A is a helix-turn-helix, nucleocytoplasmic protein of approximately $250 \mathrm{kDa}$, whose stability varies according to its subcellular location [5]. ARID1A gene expression is downregulated in $S$ and $G_{2} / M$ phases and is up-regulated in the $G_{0} / G_{1}$ phase, which supports the role of $A R I D 1 A$ at the $\mathrm{G}_{1}$ checkpoint for the proper arrest of cell cycle progression [6]. ARID1A is involved in the modulation of various cellular processes that are vital in preventing tumor initiation and progression via regulating the downstream transcriptional activity of several proto-oncogenes and tumor suppressor genes (TSGs) [7]. ARID1A gene possesses a high frequency of somatic mutation in several types of malignancies leading to reduced or loss of expression, which in turn exhibits a positive correlation with tumorigenicity $[6,8]$. Limited studies have evaluated the possible role of ARID1A so far. Loss of $A R I D 1 A$ expression was reported in $11-51.3 \%$ of GCs and related to poor clinical parameters and shorter survival of GC patients [9-10].

TP53 is a well-studied tumor suppressor gene that plays a key role in regulating the cell cycle. It is a principal mediator of growth arrest, senescence and apoptosis in response to a broad array of cellular damage [11]. Interestingly, The SWI/SNF complex interacts directly or indirectly with TP53 and regulates the transcription of target genes downstream of TP53, thereby suggesting that ARID1A plays important roles in tumor suppression [4, 12]. Some studies have reported that mutation and aberrant expression of TP53 are negatively associated with ARID1A loss [13].

PDL1, a molecule able to down-regulate immune response, is thought to play an important role in the persistence of chronic infections and evasion of immune destruction by tumor cells [14]. PD1 acts as a T-cells inhibitor mainly by limiting T-cells activity within neoplastic tissues and its ligand, PDL1, is often overexpressed on tumor cells [15]. As per previous studies, PDL1 was overexpressed in various cancers including GC [16-18]. However, the prognostic relevance of PDL1 protein expression in GC remains controversial, and prior studies have shown that PDL1 plays a promotive or suppressive role in GC [19]. It was also reported that ARID1A expression is related to PDL1 levels in various cancers [16-18].

At present, the outcome for patients with advanced GC is still bleak [20]. Efforts have been directed toward identifying novel biomarkers for aggressive disease and new molecular targets for therapeutic intervention. Therefore, in this study, we investigated the mutation spectrum on exon-9 and expression of ARID1A along with expression of TP53 and PDL1 genes in GC. Furthermore, we also correlate the expression with various clinicopathological parameters to have an idea about the role of ARID1A in the genesis of GC.

\section{MATERIALS AND METHODS}

\section{Study Design}

This was a cross-sectional study conducted by the Department of Biochemistry and General Surgery, Government Medical College Srinagar and Associated Shri Maharaja Hari Singh (SMHS) and Superspeciality Hospital, Srinagar, Kashmir, J\&K, India.

\section{Study Subjects and Sample Collection}

The study included histopathologically confirmed 103 Gastric tumor tissue samples along with their adjacent normal tissue collected from the Department of Surgery, Shri Maharaja Hari Singh (SMHS) Hospital, Srinagar from March 2017 to March 2020. Adjacent normal tissue contained normal gastric mucosa present near the margins of resection, away from the tumor. The clinicopathological information of the patients was obtained from the Medical Records Department of hospital. All the GC cases were newly diagnosed intestinal type adenocarcinomas and did not receive any chemo or radiotherapy. The included GC cases were not having any other type of tumour and were free from any genetic disorder. One aliquot of tissue sample was snap-frozen immediately and stored at $-80^{\circ} \mathrm{C}$ till further processing for DNA analysis. Another aliquot of tissue sample was immediately stored in $R N A$-later (Sigma-Aldrich, United States) at $4^{\circ} \mathrm{C}$ overnight, to allow the solution to thoroughly penetrate the tissue before stored at $-80^{\circ} \mathrm{C}$ to prevent any degradation until RNA isolation.

\section{DNA Isolation}

DNA was extracted from tissue samples using QIAamp DNA Mini kit (Qiagen, Germany) according to the given protocol. The quality of the DNA was verified using $1 \%$ agarose gel electrophoresis. The concentration and purity of DNA was measured using NanoDrop 2000c Spectrophotometer (ThermoFisher Scientific, United States). The DNA samples of high molecular weight, without any fragmentation/shearing, with OD (260/280) ratio between 1.8 and 1.9 were processed for further molecular analysis.

\section{Polymerase Chain Reaction Followed by DNA Sequencing}

Exon-9 of ARID1A gene was amplified using primers: forward: 5'CACAGCACTATTTGGCTCCAG-3'; reverse: 5'-ATCATC TCTGGGCTGGCTG-3' (Eurofins Genomics, Germany). The PCR amplification was carried out in a $50 \mu$ l volume containing $12.5 \mu \mathrm{l}$ of $2 \mathrm{X}$ PCR master mix (3B BlackBio, Biotech, India), $0.2 \mu \mathrm{M}$ of each forward and reverse primers, $50-150 \mathrm{ng}$ of genomic DNA. After initial denaturation at $94^{\circ} \mathrm{C}$ for $7 \mathrm{~min}, 35$ cycles of denaturation at $94^{\circ} \mathrm{C}$ for $20 \mathrm{~s}$, annealing at $58^{\circ} \mathrm{C}$ for $30 \mathrm{~s}$, and extension at $72^{\circ} \mathrm{C}$ for $30 \mathrm{~s}$ were performed. The final extension was given at $72^{\circ} \mathrm{C}$ for $7 \mathrm{~min}$. The $343 \mathrm{bp}$ amplified product was verified on $2.5 \%$ agarose gel and visualized on Omega Lum G Gel Documentation centre (Aplegen, United States).

\section{DNA Sequencing}

The amplified samples were sequenced, using ABI prism 310 automated DNA sequencer (ThermoFisher Scientific, United States) via Sanger dideoxy method.

\section{RNA Isolation Followed by cDNA Synthesis}

Total RNA was extracted from tissue samples using TRIzol reagent (ThermoFisher Scientific, United States). The concentration and purity of RNA was measured using NanoDrop 2000c Spectrophotometer (ThermoScientific, 
United States). RNA having A260/A280 between 1.8 and 2.0 was considered as "Uncontaminated." Furthermore, RNA integrity was also verified by the presence of $28 \mathrm{~S}, 18 \mathrm{~S}$ and $5 \mathrm{~S}$ rRNA bands on $1.5 \%$ agarose gel. The first strand cDNA was synthesized with DNase-treated RNA; 1-2 $\mu$ g RNA was reverse transcribed into cDNA using RevertAid First Strand cDNA Synthesis Kit (ThermoFisher Scientific, United States), according to the manufacturer's instructions. The reactions were incubated for $60 \mathrm{~min}$ at $37^{\circ} \mathrm{C}$ followed by $95^{\circ} \mathrm{C}$ for $10 \mathrm{~min}$.

\section{Quantitative Real Time-PCR for Relative mRNA Expression of ARID1A, TP53 and PDL1}

qRT-PCR was performed using 7500 Real-Time PCR system (ThermoFisher Scientific, United States). The primers sequences used were; ARID1A forward $5^{\prime}$-CTTCAACCTCAG TCAGCTCCCA-3', ARID1A reverse $5^{\prime}$-GGTCACCCACCTCAT ACTCCTTT-3'; TP53 forward 5'-TGCGTGTGGAGTATTTGG ATG-3', TP53 reverse $5^{\prime}$-TGGTACAGTCAGAGCCAACCTC3'; PDL1 forward 5'-ACTGGCATTTGCTGAACGCA-3', PDL1 reverse $5^{\prime}$ - AGACAATTAGTGCAGCCAGGTCT-3'; GAPDH forward 5'- CTCCTCCTGTTCGACAGTCAGC-3; GAPDH reverse, 5' - CCCAATACGACCAAATCCGTT-3' [10, 21-22]. The GAPDH (housekeeping gene) was used as an internal control. The PCR reaction mixture contained $10 \mu \mathrm{l}$ of $K A P A$ $S Y B R^{\circledR}$ FAST master mix (Sigma-Aldrich, United States), $0.5 \mu \mathrm{l}$ of cDNA of each sample, $0.2 \mu \mathrm{M}$ of each forward and reverse primers in a final volume of $20 \mu \mathrm{l}$ adjusted with Milli-Q water. The reaction mix was preheated at $95^{\circ} \mathrm{C}$ for $10 \mathrm{~min}$ and then amplified with 40 cycles at $95^{\circ} \mathrm{C}$ for $30 \mathrm{~s}, \mathrm{X}^{\circ} \mathrm{C}$ for $1 \mathrm{~min}(\mathrm{X}=$ $60^{\circ} \mathrm{C}$ for ARID1A; $65^{\circ} \mathrm{C}$ for TP53, $56^{\circ} \mathrm{C}$ for PDL1) and $72^{\circ} \mathrm{C}$ for $35 \mathrm{~s}$. Specificity of the PCR products was determined by Melting curve analysis. All the samples were run in triplicates. The mRNA expression of ARID1A was defined on the basis of $C_{t}$ (cycle threshold) value of each sample. The relative expression was calculated by the $2^{-\Delta \Delta \mathrm{Ct}}$ method [23].

\section{Statistical Analysis}

Data analysis was performed using SPSS software V 23.0 (SPSS Inc., Chicago IL, United States). The association between ARID1A, TP53, PDL1 alterations and various sociodemographic and clinicopathological characteristics was evaluated by Pearson's $\chi^{2}$ test or Fisher's exact test for discrete variables; paired t-test for continuous variables using multiple logistic regression analysis. The odds ratios (ORs) with 95\% confidence intervals (CIs) was calculated. Two-sided $p \leq 0.05$ was considered statistically significant.

\section{RESULTS}

\section{Patient Characteristics}

Out of all GC patients taken for the study $59.3 \%$ (61 of 103) were males whereas $40.7 \%$ (42 of 103) were females. The mean age (in
TABLE 1 | Socio-demographic and clinicopathological variables of GC patients taken for the study.

\begin{tabular}{|c|c|c|}
\hline Variables & GC cases $(n=103)$ & $\%$ \\
\hline \multicolumn{3}{|l|}{ Gender } \\
\hline Male & 61 & 59.3 \\
\hline Female & 42 & 40.7 \\
\hline \multicolumn{3}{|l|}{ Age group } \\
\hline$<50$ years & 35 & 34.0 \\
\hline$\geq 50$ years & 68 & 66.0 \\
\hline \multicolumn{3}{|l|}{ Dwelling } \\
\hline Rural & 66 & 64.0 \\
\hline Urban & 37 & 36.0 \\
\hline \multicolumn{3}{|l|}{ Smoking status } \\
\hline Non-Smoker & 59 & 57.3 \\
\hline Smoker & 44 & 42.7 \\
\hline \multicolumn{3}{|l|}{ BMl $\left(\mathrm{kg} / \mathrm{m}^{2}\right)$} \\
\hline Normal & 54 & 52.4 \\
\hline Underweight & 10 & 9.7 \\
\hline Preobese & 28 & 27.2 \\
\hline Obese Class I & 09 & 8.7 \\
\hline Obese Class ॥ & 02 & 1.9 \\
\hline \multicolumn{3}{|l|}{ Family history } \\
\hline No & 86 & 83.5 \\
\hline Yes & 17 & 16.5 \\
\hline \multicolumn{3}{|c|}{ Salt tea consumption } \\
\hline$<5$ cups/day & 29 & 28.2 \\
\hline$\geq 5$ Cups/day & 74 & 71.8 \\
\hline \multicolumn{3}{|l|}{ CEA levels (ng/ml) } \\
\hline Normal & 34 & 33.0 \\
\hline Elevated & 69 & 67.0 \\
\hline H. Pylori & 65 & 63.1 \\
\hline Absent Present & 38 & 36.9 \\
\hline \multicolumn{3}{|l|}{ Stage } \\
\hline | and || & 70 & 68.0 \\
\hline III and IV & 33 & 32.0 \\
\hline \multicolumn{3}{|l|}{ Grade } \\
\hline WD & 66 & 64.0 \\
\hline PD & 37 & 36.0 \\
\hline
\end{tabular}

BMI, basal metabolic index (<18.5 = underweight, 18.5-24.99 = Normal, 25-29.99 = Preobese, 30-34.99 = Obese class I, 35-39.99 = Obese class II).

$C E A$, carcinoembryonic antigen; $\mathrm{H}$. Pylori, Helicobacter pylori; WD, well differentiated; $P D$, poorly differentiated.

years) of GC cases was $56.6 \pm 12.1$. The mean BMI in $\mathrm{kg} / \mathrm{m}^{2}$ of cases was $24.85 \pm 4.45$, while as the mean CEA levels of GC cases was $6.07 \pm 2.04 \mathrm{ng} / \mathrm{ml} 57.3 \%$ of GC cases were non-smokers and $42.7 \%$ were smokers. H. Pylori status was positive in $36.9 \%$ (38 of 103) of GC patients. The detailed socio-demographic and clinicopathological parameters of GC patients are given in Table 1.

\section{Mutational Analysis of ARID1A Gene}

In the present study, Gastric tumor tissue samples were screened along with their adjacent non-tumor tissue samples for the presence of mutations, if any. On DNA sequencing of amplified exon-9 of ARID1A gene, we detected a nonsense mutation (c. $3219 \mathrm{C}>\mathrm{T}$ ) at amino acid position 1073, among 02 out of $103(\sim 2.0 \%)$ GC tumor tissues samples leading to formation of stop codon (CAG to TAG). Mutation was not found in any of the adjacent normal tissue samples. Figure 1 shows the partial electrophoretograms depicting the c.3219; C > T mutation in exon-9 of ARID1A gene. 


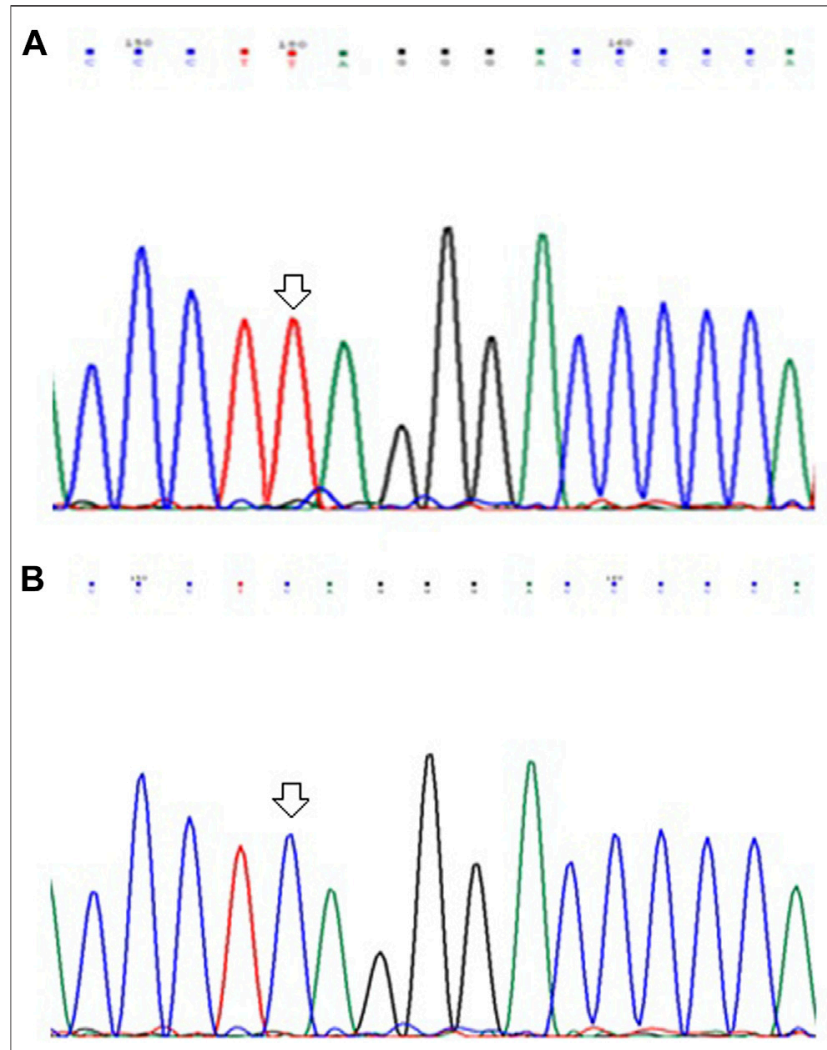

FIGURE 1 | Partial electrophoretograms (forward) of DNA sequences in exon-9 of ARID1A gene in $\mathrm{GC}$ cases showing (A) $\mathrm{C}$ to $\mathrm{T}$ substitution at nucleotide position 3219 and (B) Sequence without any mutation.

\section{Relative mRNA Expression of ARID1A, TP53, PDL1 in GC}

We performed qRT-PCR to investigate ARID1A, TP53 and PDL1 mRNA expression in 103 Gastric tumor tissues and their adjacent normal tissue samples. The melt curve analysis showed zero formation of any non-specific products. Figures 2-4 contains box and whisker plots depicting the relative mRNA expression of ARID1A, TP53 and PDL1 in GC cases in terms of their $\Delta \mathrm{C}_{\mathrm{t}}$ values. There was a significant decrease in the mRNA expression of ARID1A in Gastric tumor tissues compared to adjacent normal tissues $\left(\Delta \mathrm{C}_{\mathrm{t}}\right.$ tumor vs. $\Delta \mathrm{C}_{\mathrm{t}}$ adjacent normal; $p<0.0001$; Table 2 ) with a mean fold change of 0.63 . In addition, there was a significant increase in the mRNA expression of TP53 and PDL1 in Gastric tumor tissues compared to adjacent normal tissues ( $\Delta \mathrm{C}_{\mathrm{t}}$ tumor vs. $\Delta \mathrm{C}_{\mathrm{t}}$ adjacent normal; $p<0.0001$; Table 2 ) with a mean fold change of 2.93 and 2.43 respectively.

In the present study, "increased" mRNA expression was defined as $\mathrm{N}$-fold $\geq 2.0$, "normal" expression was an $\mathrm{N}$-fold ranging from 0.5001 to 1.9999 , and "decreased" mRNA expression was $\mathrm{N}$-fold $\leq 0.5$ [24]. Using this criteria, the relative mRNA expression of the ARID1A was decreased in $25.24 \%$ (26 of 103) of GC patients (Table 3 ). The relative mRNA expression of TP53 and PDL1 was increased in $47.6 \%$ (49 of 103 ) and $39.8 \%$ (41 of 103) of GC patients respectively (Tables 4, 5).

\section{Association of Relative mRNA Expression With Various Parameters of GC Cases}

The stratification of ARID1A mRNA levels with respect to various socio-demographic and clinicopathological parameters of GC patients is given in Table 3. Among GC cases having stage I\&II disease only $18.6 \%$ were having reduced $A R I D 1 A$ mRNA expression compared to $39.4 \%$ patients with stage III\&IV disease and reduced $A R I D 1 A$ mRNA expression $(\mathrm{OR}=2.8 ; p=0.03)$. A higher percentage $(37.9 \%)$ of $\mathrm{GC}$ patients with poorly differentiated disease were having reduced ARID1A mRNA expression compared to GC patients with well differentiated disease $(18.2 \%)(\mathrm{OR}=2.7 ; p=0.03)$.

The stratification of TP53 mRNA levels with respect to various socio-demographic and clinicopathological parameters of GC patients is given in Table 4. A significantly higher percentage of Preobese GC patients were having elevated TP53 mRNA levels compared to GC patients having normal BMI and elevated TP53 mRNA levels (67.9 vs. $31.5 \%$; OR $=6.3 ; p=0.0002$ ). Among GC cases without $H$. Pylori infection $35.4 \%$ (23/65) were having TP53 mRNA overexpression compared to GC patients with $H$. Pylori infection among which $68.4 \%(26 / 38)$ were having TP53 overexpression $(\mathrm{OR}=4.0 ; p=0.002)$. Among GC cases having stage I \& II disease only $38.0 \%$ were having reduced TP53 mRNA expression compared to $68.8 \%$ patients with stage III\&IV disease and elevated TP53 mRNA expression (OR = 3.6; $p=0.005)$. A higher percentage of GC patients with poorly differentiated disease were having elevated TP53 mRNA expression compared to GC patients with well differentiated disease (34.4 vs. $69.2 \%$; OR $=4.3 ; p=0.001$ ).

The stratification of PDL1 mRNA levels with respect to various socio-demographic and clinicopathological parameters of GC patients is given in Table 5. A significantly higher percentage of GC patients with stage III \& IV disease were having elevated PDL1 mRNA levels compared to GC patients having stage I \& II disease (71.9 vs. $25.4 \%$; OR $=7.5 ; p=0.00$ ). Among GC cases with well differentiated disease only $21.9 \%$ (14/ 66) were having PDL1 mRNA overexpression compared to GC patients with poorly differentiated disease among which $69.2 \%$ (27/37) were having PDL1 overexpression ( $\mathrm{OR}=8.1 ; p=0.00)$.

\section{Relationship Between ARID1A, TP53 and PDL1 mRNA Expression}

Figure 5 represents a venn diagram depicting the correlation between ARID1A mRNA underexpression and mRNA overexpression of TP53 and PDL1. Only TP53 overexpression and $P D L 1$ overexpression were significantly associated with each other and the correlation was positive $(\mathrm{OR}=7.6 ; p=0.00$; Table 4).

\section{DISCUSSION}

The clinical symptoms of GC are often commenced at an advanced stage, resulting in the limitation of diagnosis and therapeutic approaches to around $50 \%$ of cancerous cases [25]. 


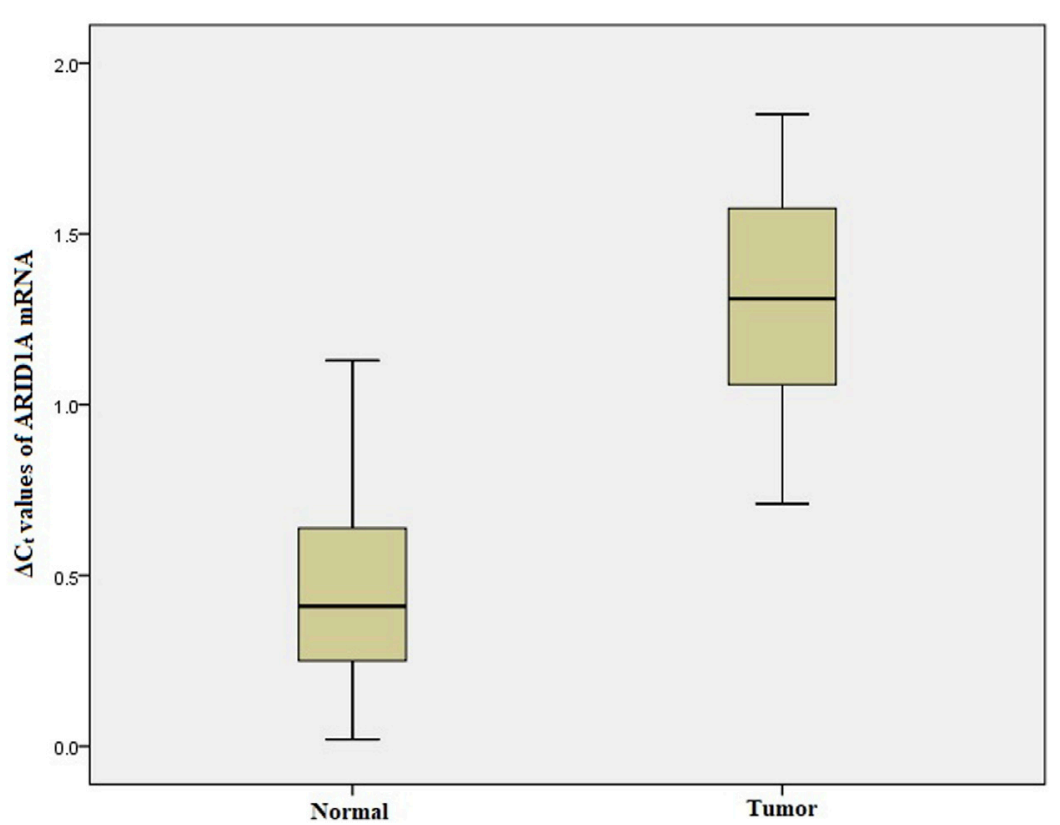

FIGURE 2 | Box and whisker plot depicting the relative mRNA expression of ARID1A in terms of $\triangle$ Ct values of GC tumor tissues and adjacent normal tissues (controls). The experiment was performed in triplets. The relative mRNA expression of ARID1A was significantly lower in Gastric tumors tissue samples compared to adjacent non-tumorous tissues $(p<0.001)$. Data was represented as mean \pm SD.

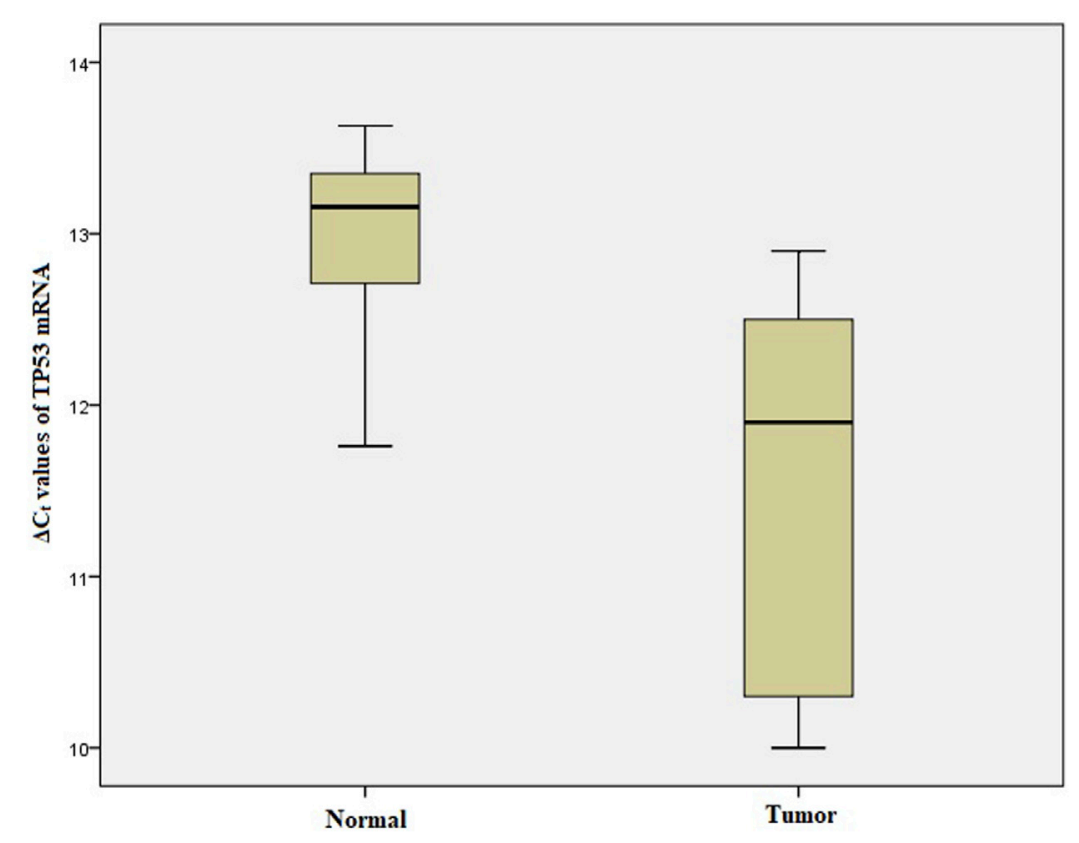

FIGURE 3 | Box and whisker plot depicting the relative mRNA expression of TP53 in terms of $\triangle$ Ct values of GC tumor tissues and adjacent normal tissues (controls). The experiment was performed in triplets. The relative mRNA expression of TP53 was significantly lower in Gastric tumors tissue samples compared to adjacent non-tumorous tissues $(p<0.001)$. Data was represented as mean \pm SD.

However, over the past decade, there has been a striking improvement in cancer management and treatment by understanding the genetics of disease.
ARID1A has recently emerged as a novel tumor suppressor gene, as per the evidence supporting the positive association between reduced ARID1A expression and tumorigenicity of 


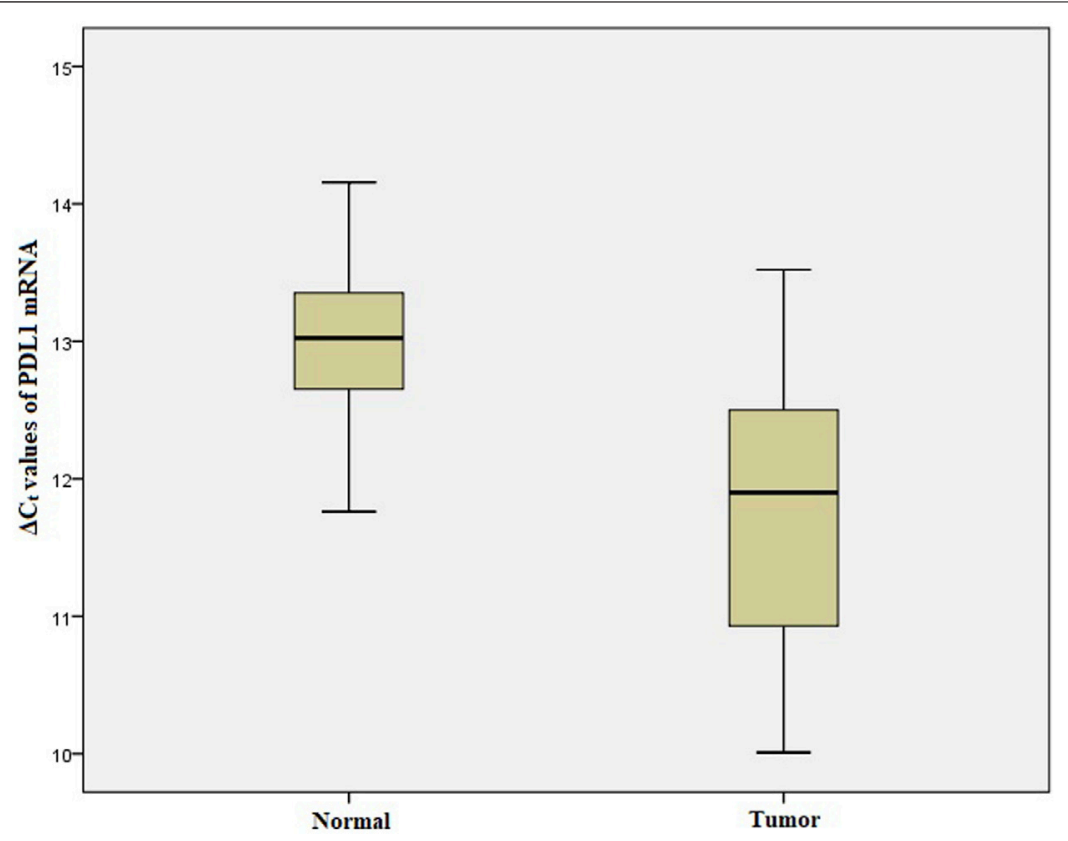

FIGURE 4 | Box and whisker plot depicting the relative mRNA expression of PDL1 in terms of $\triangle \mathrm{Ct}$ values of GC tumor tissues and adjacent normal tissues (controls). The experiment was performed in triplets. The relative mRNA expression of PDL1 was significantly lower in Gastric tumors tissue samples compared to adjacent non-tumorous tissues $(p<0.001)$. Data was represented as mean \pm SD.

TABLE 2 | Comparison of mRNA expression of ARID1A, TP53 and PDL1 gene between GC tumor tissues and adjacent normal tissues.

\begin{tabular}{|c|c|c|c|c|}
\hline Gene & $\begin{array}{c}\text { Gastric tumor tissues } \\
\left.\qquad \Delta \mathbf{C}_{\mathrm{t}} \text { (mean } \pm \mathrm{SD}\right)\end{array}$ & $\begin{array}{l}\text { Adjacent normal tissue } \\
\left.\qquad \Delta \mathrm{C}_{\mathrm{t}} \text { (mean } \pm \mathrm{SD}\right)\end{array}$ & $\begin{array}{c}\text { Mean } \\
\text { fold change }\left(2^{-\Delta \Delta C T}\right)\end{array}$ & $p$-Value \\
\hline$A R I D 1 A$ & $1.3 \pm 0.34$ & $0.53 \pm 0.38$ & 0.63 & $<0.0001$ \\
\hline TP53 & $11.45 \pm 1.0$ & $13.0 \pm 0.42$ & 3.93 & $<0.0001$ \\
\hline PDL1 & $11.63 \pm 0.97$ & $12.91 \pm 0.5$ & 3.2 & $<0.0001$ \\
\hline
\end{tabular}

several cancers, such as ovarian, endometrial, cervical, breast, gastric, colorectal, and lung cancers $[7,10,26]$. We investigated the status of ARID1A mutation in GC wherein we detected a nonsense mutation (c.3219; C > T) among two ( 2.0\%) GC patients that introduces a premature stop codon leading to the abortive termination of the ARID1A protein, thereby resulting in its complete or partial inactivation and reduced or loss of protein function. Mamo et al. previously reported nonsense mutation in exon-9, which introduces the premature stop codon into coding sequence at position W1073 [27]. Furthermore, studies have reported that frequency of this nonsense mutation is usually low in tumor cells [27, 28]. However, the general mutation rate of the ARIDIA gene varies between 8 and $39 \%$ in gastrointestinal cancers [29] and between 8 and 29\% in GC [26]. Earlier studies have demonstrated that ARID1A mutations were more frequent in Gastric tumors, especially with microsatellite instability and Epstein-Barr virus infection [10, 29]. The nonsense mutation of ARIDIA, resulting in loss of its functional protein, consequently leads to the activation of the PI3K/AKT pathway that promotes several mechanisms responsible for carcinogenesis, including cell proliferation, inhibition of apoptosis, cell adhesion, and transformation $[5,30]$. Several studies have reported that the siRNA knockdown of ARID1A increases phosphorylations of AKT and promotes cell division and metastasis $[5,30]$.

Our result revealed that ARIDIA was under-expressed at mRNA level in $25.6 \%$ of GC cases with an average fold change of 0.63. Consistent with our study, Yang et al. found that the expressional loss of ARID1A was frequent in 30\% of GC patients and has a significant correlation with poor survival and prognosis [31]. However, Wang et al. revealed that ARID1A was significantly lower in 65.15 and $52 \%$ of GC patients at mRNA and protein level respectively [10]. Previously it has been reported that about $30 \%$ of Caucasians, $25 \%$ of Asians and $10 \%$ of Pacific Islanders exhibited loss of ARID1A expression in clear cell and endometrioid ovarian carcinoma [31]. Additionally, there was no significant difference when comparing individuals of Japanese and non-Japanese origin with respect to their decreased ARID1A expression in ovarian cancer (29 vs. 18\%) [31]. The expressional loss of ARID1A has been shown to trigger the initiation and progression of carcinogenesis in numerous types of cancers, including ovarian, breast, endometrial and cervical, breast, gastric, and colorectal cancers through several mechanisms 
TABLE 3 | Association of ARID1A mRNA expression with socio-demographic and clinicopathological variables of GC patients.

\begin{tabular}{|c|c|c|c|c|c|}
\hline \multirow[t]{2}{*}{ Variables } & \multirow[t]{2}{*}{ Cases N = $103(\%)$} & \multicolumn{2}{|c|}{ ARID1A mRNA expression } & \multirow[t]{2}{*}{ OR (95\% Cl) } & \multirow[t]{2}{*}{$p$-Value } \\
\hline & & Normal 77 (74.8\%) & Reduced 26 (25.2\%) & & \\
\hline \multicolumn{6}{|l|}{ Gender } \\
\hline Male & 61 (59.) & $42(68.8)$ & 19 (31.2) & 1.00 & 0.10 \\
\hline Female & $42(40.7)$ & 35 (83.3) & 07 (16.7) & $0.4(0.15-1.6)$ & \\
\hline \multicolumn{6}{|l|}{ Age group } \\
\hline$<50$ years & 35 (34.0) & $28(80.0)$ & 07 (20.0) & 1.00 & 0.40 \\
\hline$\geq 50$ years & $68(66.0)$ & $49(72.0)$ & 19 (28.0) & $1.5(0.6-4.4)$ & \\
\hline \multicolumn{6}{|l|}{ Dwelling } \\
\hline Rural & $66(64.0)$ & $51(77.2)$ & 15 (22.8) & 1.00 & 0.44 \\
\hline Urban & $37(36.0)$ & $26(70.2)$ & $11(29.8)$ & $1.4(0.56-3.6)$ & \\
\hline \multicolumn{6}{|l|}{ Smoking status } \\
\hline Non-Smoker & $59(57.3)$ & 47 (80.0) & $12(20.0)$ & 1.00 & 0.20 \\
\hline Smoker & $44(42.7)$ & $30(68.1)$ & 14 (31.9) & $1.8(0.73-4.5)$ & \\
\hline \multicolumn{6}{|l|}{ BMl $\left(\mathrm{kg} / \mathrm{m}^{2}\right)$} \\
\hline Normal & $54(52.4)$ & $41(76.0)$ & $13(24.0)$ & 1.00 & \\
\hline Underweight & $10(9.7)$ & $06(60.0)$ & 04 (40.0) & $2.1(0.45-8.8)$ & 0.3 \\
\hline Preobese & $28(27.2)$ & $22(78.5)$ & 06 (21.5) & $0.9(0.27-2.6)$ & 0.8 \\
\hline Obese Class I & $09(8.7)$ & $06(66.7)$ & 03 (33.3) & $1.6(0.3-7.2)$ & 0.5 \\
\hline Obese Class II & $02(1.9)$ & 02 (100.0) & $00(0.0)$ & $1.0(0.03-10.2)$ & 0.9 \\
\hline \multicolumn{6}{|l|}{ Family history } \\
\hline No & $86(83.5)$ & $65(75.5)$ & $21(24.5)$ & 1.00 & 0.66 \\
\hline Yes & $17(16.5)$ & $12(70.5)$ & $05(29.5)$ & $1.3(0.37-4.0)$ & \\
\hline \multicolumn{6}{|c|}{ Salt tea consumption } \\
\hline$<5$ cups/day & $29(28.2)$ & $19(65.5)$ & $10(34.5)$ & 1.00 & 0.19 \\
\hline$\geq 5$ Cups/day & $74(71.8)$ & $58(78.3)$ & $16(21.7)$ & $0.53(0.2-1.4)$ & \\
\hline \multicolumn{6}{|l|}{ CEA levels (ng/ml) } \\
\hline Normal & $34(33.0)$ & $23(67.6)$ & $11(32.4)$ & 1.00 & 0.25 \\
\hline Elevated & $69(67.0)$ & $54(78.2)$ & $15(21.8)$ & $0.58(0.2-1.4)$ & \\
\hline \multicolumn{6}{|l|}{ H. Pylori } \\
\hline Absent & $65(63.1)$ & $51(78.4)$ & 14 (21.6) & 1.00 & 0.27 \\
\hline Present & $38(36.9)$ & $26(68.4)$ & $12(31.6)$ & $1.7(0.66-4.2)$ & \\
\hline \multicolumn{6}{|l|}{ Stage } \\
\hline | and || & $70(68.0)$ & $57(81.4)$ & 13 (18.6) & 1.00 & 0.03 \\
\hline III and IV & $33(32.0)$ & $20(60.6)$ & $13(39.4)$ & $2.8(1.1-7.2)$ & \\
\hline \multicolumn{6}{|l|}{ Grade } \\
\hline WD & $66(64.0)$ & $54(81.8)$ & $12(18.2)$ & 1.00 & 0.03 \\
\hline PD & $37(36.0)$ & $23(62.1)$ & $14(37.9)$ & $2.7(1.1-6.9)$ & \\
\hline \multicolumn{6}{|c|}{ TP53 mRNA expression } \\
\hline Normal & $54(52.4)$ & $39(72.2)$ & $15(27.8)$ & 1.00 (Ref.) & 0.6 \\
\hline Reduced & 49 (47.6) & $38(77.5)$ & $11(22.5)$ & $0.7(0.3-1.8)$ & \\
\hline \multicolumn{6}{|c|}{ PDL1 mRNA expression } \\
\hline Normal & $62(60.2)$ & $46(74.1)$ & $16(25.8)$ & 1.00 (Ref.) & 0.9 \\
\hline Elevated & $41(39.8)$ & $31(75.6)$ & $10(24.4)$ & $0.9(0.3-2.3)$ & \\
\hline
\end{tabular}

BMI, basal metabolic index (<18.5 = underweight, 18.5-24.99 = Normal, 25-29.99 = Preobese, 30-34.99 = Obese class I, 35-39.99 = Obese class II).

$C E A$, carcinoembryonic antigen; H. Pylori, Helicobacter pylori; WD, well differentiated; PD, poorly differentiated.

that have not been fully elucidated [26]. Studies have reported that restoration of normal ARID1A protein levels in vitro successfully inhibits the uncontrolled cell division [26]. Chanon et al. observed that knockdown of ARID1A in three wild-type cell lines promotes the cell division in bile duct cancer, and the effect was reversed when ARID1A was ectopically re-expressed [32]. We further investigated the association of GC with clinicopathological parameters and found lower ARID1A expression in patients with the high-grade and advanced stage of the GC. Consistent with our findings, some investigations also reported that the reduced expression of the ARID1A has a significant association with higher grading and staging of GC [10]. However, several studies have also reported that loss of ARID1A expression has no significant association with advanced cancer grade and stage [33]. Although not found in our study, Chou et al. revealed that ARID1A has a significant association with age, gender, tumor location, and tumor size [34]. Our study confirmed that the mRNA levels of ARID1A were low in the two GC patients with ARID1A c.3219 C > T mutation. Consistent with our study, Mamo et al. also reported that RNA levels of ARID1A were found very low in samples with nonsense mutations [27]. The introduction of stop codon in upstream region results in abortive termination of proteins that could interfere the normal protein functions [35].

The role of TP53 in suppressing tumour growth is primarily due to its induction of cell cycle arrest and DNA repair or apoptosis, following genotoxic stress [36]. We observed a significantly higher TP53 relative mRNA expression in $47.6 \%$ 
TABLE 4 | Association of TP53 mRNA expression with socio-demographic and clinicopathological variables of GC patients.

\begin{tabular}{|c|c|c|c|c|c|}
\hline \multirow[t]{2}{*}{ Variables } & \multirow[t]{2}{*}{ Cases N = $103(\%)$} & \multicolumn{2}{|c|}{ TP53 mRNA expression } & \multirow[t]{2}{*}{ OR $(95 \% \mathrm{Cl})$} & \multirow[t]{2}{*}{$p$-Value } \\
\hline & & Normal 54 (52.4) & Elevated 49 (47.6) & & \\
\hline \multicolumn{6}{|l|}{ Gender } \\
\hline Male & $61(59.3)$ & $29(47.5)$ & $32(52.5)$ & 1.00 (Ref.) & 0.3 \\
\hline Female & $42(40.7)$ & $25(59.5)$ & $17(40.5)$ & $0.6(0.3-1.4)$ & \\
\hline \multicolumn{6}{|l|}{ Age group } \\
\hline$<50$ years & $35(34.0)$ & $21(60.0)$ & $14(40.0)$ & 1.00 (Ref.) & 0.3 \\
\hline$\geq 50$ years & $68(66.0)$ & $33(48.5)$ & 35 (51.5) & $1.6(0.7-3.6)$ & \\
\hline \multicolumn{6}{|l|}{ Dwelling } \\
\hline Rural & $66(64.0)$ & $37(56.1)$ & $29(43.9)$ & 1.00 (Ref.) & 0.4 \\
\hline Urban & 37 (36.0) & 17 (45.9) & $20(54.1)$ & $1.5(0.7-3.3)$ & \\
\hline \multicolumn{6}{|l|}{ Smoking status } \\
\hline Non-Smoker & 59 (57.3) & $36(59.0)$ & $25(41.0)$ & 1.00 (Ref.) & 0.1 \\
\hline Smoker & $44(42.7)$ & $18(42.9)$ & $24(57.1)$ & $1.9(0.8-4.2)$ & \\
\hline \multicolumn{6}{|l|}{ BMI $\left(\mathrm{kg} / \mathrm{m}^{2}\right)$} \\
\hline Normal & $54(52.4)$ & 37 (68.5) & $17(31.5)$ & 1.00 (Ref.) & \\
\hline Underweight & $10(9.7)$ & 05 (50.0) & $05(50.0)$ & $2.1(0.5-9.0)$ & 0.2 \\
\hline Preobese & $28(27.2)$ & $07(32.1)$ & $21(67.9)$ & $6.3(2.3-18.9)$ & 0.0002 \\
\hline Obese Class I & $09(8.7)$ & $04(66.7)$ & 05 (33.3) & $2.6(0.6-12.5)$ & 0.2 \\
\hline Obese Class II & $02(1.9)$ & 01 (100.0) & $01(0.0)$ & $2.1(0.05-8.7)$ & 0.6 \\
\hline \multicolumn{6}{|l|}{ Family history } \\
\hline No & $86(83.5)$ & $47(53.4)$ & 41 (46.6) & 1.00 (Ref.) & 0.7 \\
\hline Yes & $17(16.5)$ & 07 (46.7) & 08 (53.3) & $1.3(0.4-3.9)$ & \\
\hline \multicolumn{6}{|c|}{ Salt tea consumption } \\
\hline$<5$ cups/day & $29(28.2)$ & $19(65.5)$ & $10(34.5)$ & 1.00 (Ref.) & 0.1 \\
\hline$\geq 5$ Cups/day & $74(71.8)$ & 35 (47.3) & $39(52.7)$ & $2.1(0.8-5.3)$ & \\
\hline \multicolumn{6}{|l|}{ CEA levels (ng/ml) } \\
\hline Normal & 34 (33.0) & 37 (53.6) & $32(46.4)$ & 1.00 (Ref.) & 0.8 \\
\hline Elevated & 69 (67.0) & 17 (50.0) & $17(50.0)$ & $1.2(0.5-2.6)$ & \\
\hline \multicolumn{6}{|l|}{ H. Pylori } \\
\hline Absent & $65(63.1)$ & $42(64.6)$ & $23(35.4)$ & 1.00 (Ref.) & 0.002 \\
\hline Present & $38(36.9)$ & $12(31.6)$ & $26(68.4)$ & $4.0(1.7-9.2)$ & \\
\hline \multicolumn{6}{|l|}{ Stage } \\
\hline | and || & $70(68.0)$ & $44(62.0)$ & 27 (38.0) & 1.00 (Ref.) & 0.005 \\
\hline III and IV & $33(32.0)$ & $10(31.3)$ & $22(68.8)$ & $3.6(1.5-8.7)$ & \\
\hline \multicolumn{6}{|l|}{ Grade } \\
\hline WD & $66(64.0)$ & $42(65.6)$ & $22(34.4)$ & 1.00 (Ref.) & 0.001 \\
\hline PD & 37 (36.0) & $12(30.8)$ & 27 (69.2) & $4.3(1.8-10.0)$ & \\
\hline \multicolumn{6}{|c|}{ PDL1 mRNA expression } \\
\hline Normal & $62(60.2)$ & $44(71.0)$ & $18(29.0)$ & 1.00 (Ref.) & 0.00 \\
\hline Elevated & $41(39.8)$ & $10(24.4)$ & $31(75.6)$ & $7.6(3.1-18.6)$ & \\
\hline
\end{tabular}

BMI, basal metabolic index (<18.5 = underweight, 18.5-24.99 = Normal, 25-29.99 = Preobese, 30-34.99 = Obese class I, 35-39.99 = Obese class II).

CEA, carcinoembryonic antigen; $\mathrm{H}$. Pylori, Helicobacter pylori; WD, well differentiated; $P D$, poorly differentiated.

of GC cases. The mean level of TP53 mRNA expression was almost 3 fold higher in GC tumours than in adjacent normal mucosa. In our study, some GC tumours showed high TP53 mRNA levels, while others showed a slight increase. So, TP53 mRNA may either be weakly expressed in all tumour cells or highly expressed in a few tumour cells owing to tumour heterogeneity. Our results clearly demonstrate that TP53 regulation may occur at a pretranslational step, involving either an increase in TP53 gene expression and/or stabilization of its mRNA which might lead to elevated content of TP53 protein in the cell. Although there is a particular paucity of studies that have analysed the relative expression of TP53 mRNA in cancer, TP53 has been shown to express at a high frequency in gastric adenocarcinomas [37]. In line with our observation TP53 mRNA expression was significantly higher in triple-negative breast cancer (TNBC) [38]. Our findings confirm earlier reports, which showed an elevated level of TP53 transcripts in $70 \%$ [39] and 66\% [40] of tested CRC tumours respectively. Overexpression of TP53 mRNA has recently been shown to increase the amount of endogenous TP53 and to increase apoptosis in human melanoma cells, in part, by modulating the transcription of downstream target genes including downregulation of p21 and upregulation of TP53-induced death domain protein, to favour apoptosis rather than cell cycle arrest [41]. Reports suggest that overexpressed mRNA can enhance or inhibit the ability of TP53 to trans activate certain target promoters and to induce apoptosis [42]. Thus, regulated expression of TP53 isoforms is critical for the biological outcome of TP53.

On stratification, we observed a significant association of elevated TP53 mRNA levels with higher stage and higher grade of GC. In tune with our observations, Fenoglio-Preiser 
TABLE 5 | Association of PDL1 mRNA expression with socio-demographic and clinicopathological variables of GC patients.

\begin{tabular}{|c|c|c|c|c|c|}
\hline \multirow[t]{2}{*}{ Variables } & \multirow[t]{2}{*}{ Cases N = $103(\%)$} & \multicolumn{2}{|c|}{ PDL1 mRNA expression } & \multirow[t]{2}{*}{ OR (95\% Cl) } & \multirow[t]{2}{*}{$p$-Value } \\
\hline & & Normal 62 (60.2) & Elevated 41 (39.8) & & \\
\hline \multicolumn{6}{|l|}{ Gender } \\
\hline Male & $61(59.3)$ & $36(59.0)$ & $25(41.0)$ & 1.00 (Ref.) & 0.8 \\
\hline Female & $42(40.7)$ & $26(61.9)$ & $16(38.9)$ & $0.8(0.4-2.0)$ & \\
\hline \multicolumn{6}{|l|}{ Age group } \\
\hline$<50$ years & 35 (34.0) & $22(62.9)$ & $13(37.1)$ & 1.00 (Ref.) & 0.8 \\
\hline$\geq 50$ years & $68(66.0)$ & $40(58.8)$ & $28(41.2)$ & $1.2(0.5-2.7)$ & \\
\hline \multicolumn{6}{|l|}{ Dwelling } \\
\hline Rural & $66(64.0)$ & $42(63.6)$ & $24(36.4)$ & 1.00 (Ref.) & 0.4 \\
\hline Urban & 37 (36.0) & $20(54.1)$ & 17 (45.9) & $1.5(0.6-3.4)$ & \\
\hline \multicolumn{6}{|l|}{ Smoking status } \\
\hline Non-Smoker & 59 (57.3) & $45(73.8)$ & $16(26.2)$ & 1.00 (Ref.) & 0.001 \\
\hline Smoker & $44(42.7)$ & $17(40.5)$ & $25(59.5)$ & $4.1(1.8-9.6)$ & \\
\hline \multicolumn{6}{|l|}{$\mathrm{BMI}\left(\mathrm{kg} / \mathrm{m}^{2}\right)$} \\
\hline Normal & $54(52.4)$ & $36(66.7)$ & 18 (33.3) & 1.00 (Ref.) & \\
\hline Underweight & $10(9.7)$ & $09(90.0)$ & $01(10.0)$ & $0.2(0.009-1.5)$ & 0.1 \\
\hline Preobese & $28(27.2)$ & $13(46.4)$ & $15(53.6)$ & $2.2(0.9-5.9)$ & 0.08 \\
\hline Obese Class I & $09(8.7)$ & 03 (33.3) & $06(66.7)$ & $3.9(0.8-21.1)$ & 0.07 \\
\hline Obese Class II & $02(1.9)$ & $01(50.0)$ & $01(50.0)$ & $1.9(0.04-8.1)$ & 0.6 \\
\hline \multicolumn{6}{|l|}{ Family history } \\
\hline No & $86(83.5)$ & $51(58.0)$ & 37 (42.0) & 1.00 (Ref.) & 0.4 \\
\hline Yes & 17 (16.5) & $11(73.3)$ & $04(26.7)$ & $0.5(0.1-1.7)$ & \\
\hline \multicolumn{6}{|c|}{ Salt tea consumption } \\
\hline$<5$ cups/day & $29(28.2)$ & $20(70.0)$ & $09(30.0)$ & 1.00 (Ref.) & 0.2 \\
\hline$\geq 5$ Cups/day & $74(71.8)$ & $42(56.7)$ & 32 (43.3) & $1.68(0.7-4.3)$ & \\
\hline \multicolumn{6}{|l|}{ CEA levels (ng/ml) } \\
\hline Normal & 34 (33.0) & $42(60.9)$ & 27 (39.1) & 1.00 (Ref.) & 0.9 \\
\hline Elevated & $69(67.0)$ & $20(58.8)$ & $14(41.2)$ & $1.1(0.5-2.5)$ & \\
\hline \multicolumn{6}{|l|}{ H. Pylori } \\
\hline Absent & $65(63.1)$ & $44(67.7)$ & 21 (32.3) & 1.00 (Ref.) & 0.06 \\
\hline Present & 38 (36.9) & $18(47.4)$ & $20(52.6)$ & $2.3(1.1-5.3)$ & \\
\hline \multicolumn{6}{|l|}{ Stage } \\
\hline | and || & $70(68.0)$ & $53(74.6)$ & $18(25.4)$ & 1.00 (Ref.) & 0.00 \\
\hline III and IV & 33 (32.0) & $09(28.1)$ & $23(71.9)$ & $7.5(2.9-19.2)$ & \\
\hline \multicolumn{6}{|l|}{ Grade } \\
\hline WD & $66(64.0)$ & $50(78.1)$ & $14(21.9)$ & 1.00 (Ref.) & 0.00 \\
\hline PD & 37 (36.0) & $12(30.8)$ & 27 (69.2) & $8.1(3.3-19.8)$ & \\
\hline
\end{tabular}

BMI, basal metabolic index (<18.5 = underweight, 18.5-24.99 = Normal, 25-29.99 = Preobese, 30-34.99 = Obese class I, 35-39.99 = Obese class II).

CEA, carcinoembryonic antigen; H. pylori, Helicobacter pylori; WD, well differentiated; PD, poorly differentiated.

et al. has reported TP53 overexpression in almost 90\% of invasive Gastric tumors [43]. Increased expression of TP53 mRNA in ovarian and renal cell carcinoma has been associated with worse prognosis and higher tumour grade [44]. As per previous studies, the degree of TP53 expression correlates positively with the proliferative rate of the tumors [45] and there is a tendency for TP53 expression to be more common in poorly differentiated tumors than in well differentiated lesions [46]. Kakeji et al. [47] showed that tumors with TP53-positive staining had a higher proliferative activity than did those that stained negative. Previously, breast cancer tumors of highly malignant potential and poor prognosis showed higher expression of TP53 protein [21]. In contradiction with our study, TP53 mRNA overexpression was associated with lower recurrence rates and higher overall survival rates in breast cancer and gastric cancer [37, 48]. In addition, no correlation was found between TP53 mRNA, tumour stage and disease prognosis in CRC and GC [49, 50]. Similarly, as per few previous studies, no correlation was found between positive TP53 tissue status and histological grade of tumor differentiation [51]. It has been suggested that TP53 mRNA also harbours information that helps control TP53 protein turnover rate [52].

In our study, most of the GC patients with $H$. Pylori infection had significantly increased TP53 mRNA levels. Shiao et al. observed overexpression of TP53 in 15\% of H. Pylori-positive chronic gastritis patients but $38 \%$ of $H$. Pylori-positive metaplastic gastritis patients [53]. It has been confirmed that infection from H. Pylori is a major cause of chronic inflammation of the human gastric antral mucosa leading to development of atrophic chronic gastritis and Gastric carcinoma (CG) [54]. In consonance with our study, it has been shown that H. Pylori infection increased TP53 expression and the apoptosis rate in GC [55]. Wei et al. found that TP53 levels before H. Pylori infection were low or undetectable and were elevated on exposure to $H$. Pylori infection accompanied with intense inflammation [56]. According to a study by Ahmed et al. cells cultivated with $H$. Pylori were found to be in phase G1 of the cell cycle with TP53 overexpression suggesting that cell cycle arrest in G1 is associated 


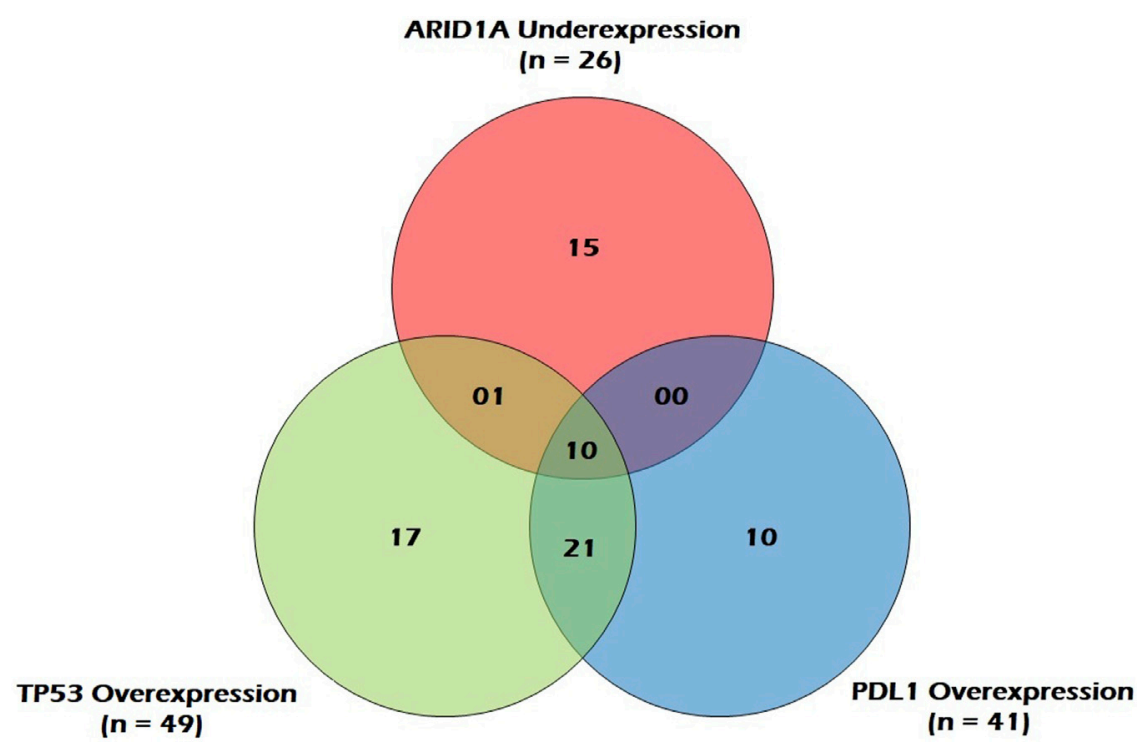

FIGURE 5 | Venn Diagram depicting correlation between ARID1A mRNA underexpression and mRNA overexpression of TP53 and PDL1 in GC patients.

with a reduction in cyclin E levels and an increase in TP53 and p21 expression showing that $H$. Pylori can induce cell stress, reduce the ability to repair damaged cells, and can increase the number of changes in the genome, leading to genetic instability and finally to GC [57].

PD1 acts as a T-cells inhibitor mainly by limiting T-cells activity within neoplastic tissues and its ligand, PDL1, is often overexpressed on tumor cells [18]. In our study, PDL1 relative mRNA expression was significantly higher in $39.8 \%$ of GC cases with an average fold change of 2.43 in tumor tissues compared to adjacent normal tissues. $\mathrm{Wu}$ et al. showed that immunohistochemical PDL1 expression was strongly positive in $42.2 \%$ of 102 human gastric carcinomas, weakly positive in adenoma samples and totally negative in normal gastric tissue [58]. PDL1 expression has been reported in a wide variety of solid tumors, including lung cancer, hepatocellular carcinoma and intra-hepatic cholangiocarcinoma, gastric, colorectal, pancreatic, ovarian, breast, cervical and oral cancer, head and neck squamous cell carcinomas, nasopharyngeal, esophageal, urothelial and renal cell cancer, nephroblastoma, melanoma and gliomas $[58,59]$. It has been suggested that $\mathrm{CD}^{+} \mathrm{T}$ cells upregulate PD1 expression and secrete IFN- $\gamma$ when they encounter tumor antigens, resulting in the upregulation of PDL1 expression on tumor cells and immune cells and the ligation of PDL1 with PD1 will decrease $\mathrm{T}$ cell function and create a negative feedback mechanism that decreases antitumor immunity leading to tumorigenesis [22]. In contradiction with our observation, no statistically significant differences were found with regard to PDL1 mRNA levels within normal and GC specimens as previously verified by Chen et al. [60].

On stratification, we observed a significant association of elevated PDL1 mRNA levels with higher stage and higher grade of GC. PDL1 overexpression has been associated to higher number of lymph node metastasis, larger tumor size, increased depth of invasion and poorer overall survival in various cancers $[58,61]$. According to a previous study, PD1, PDL1 and CD8 mRNA levels were significantly higher in undifferentiated GC [22]. More recently, it was demonstrated that PDL1 overexpression was a worse prognostic factor in GC [19].

In our study, we observed a positive correlation between TP53 and $P D L 1$ mRNA expression, suggesting that there is a synergistic effect between PDL1 and TP53 in the occurrence and development of tumors, which has also been demonstrated in NSCLC wherein TP53 has been shown to regulate PDL1 expression via miR-34 that binds PDL1 $3{ }^{\prime}$-untranslated region in NSCLC models $[62,63]$. Moreover, the expression of PDL1 and TP53 has previously been positively correlated [64]. All these studies including ours' linked tumor immune evasion to other tumor suppressor pathways previously described for TP53 [65].

\section{Conclusion}

In summary, we observed down regulation of ARID1A mRNA expression and upregulation of TP53 and PDL1 mRNA expression in GC which was in turn significantly associated high-grade and advanced stage of tumor suggesting that lower ARID1A expression and higher expression of TP53 and PDL1 might play a definite role in the initiation and progression of GC. Furthermore, a positive correlation was found between TP53 and PDL1 mRNA expression. This should be useful for future antitumour research and for the design of therapeutic agents specific to the inactivation process. However, further largescale and comprehensive researches are needed to support our results and conclusion. 


\section{DATA AVAILABILITY STATEMENT}

The data will be made available upon reasonable request.

\section{ETHICS STATEMENT}

The study was approved by the Institutional Ethical Committee, Government Medical College Srinagar, Kashmir (No. 66/ETH/ GMC). All the samples were collected after taking written informed consent from the patients and proper ethical procedures were followed.

\section{AUTHOR CONTRIBUTIONS}

Conceptualization: JQ and MK; Data curation: JQ and MK; Formal analysis: MK; Funding acquisition: SM; Investigation: JQ, MK, MW, FR, and SB; Methodology: JQ, MK, and SM; Project administration: SM; Resources: SM; Software: JQ and MK; Supervision: SM; Validation: MK; Visualization: JQ, MK, MW,

\section{REFERENCES}

1. Sung H, Ferlay J, Siegel RL, Laversanne M, Soerjomataram I, Jemal A, et al. Global Cancer Statistics 2020: GLOBOCAN Estimates of Incidence and Mortality Worldwide for 36 Cancers in 185 Countries. CA A Cancer J Clin (2021) 71:209-49. doi:10.3322/caac.21660

2. Qurieshi MA, Khan SMS, Masoodi MA, Qurieshi U, Ain Q, Jan Y, et al. Epidemiology of Cancers in Kashmir, India: an Analysis of Hospital Data. Adv Prev Med (2016) 2016:1-6. doi:10.1155/2016/ 1896761

3. Oki E, Kakeji Y, Zhao Y, Yoshida R, Ando K, Masuda T, et al. Chemosensitivity and Survival in Gastric Cancer Patients with Microsatellite Instability. Ann Surg Oncol (2009) 16:2510-5. doi:10.1245/s10434-009-0580-8

4. Wilson BG, Roberts CWM. SWI/SNF Nucleosome Remodellers and Cancer. Nat Rev Cancer (2011) 11:481-92. doi:10.1038/nrc3068

5. Samartzis E, Noske A, Dedes K, Fink D, Imesch P. ARID1A Mutations and PI3K/AKT Pathway Alterations in Endometriosis and EndometriosisAssociated Ovarian Carcinomas. Int J Mol Sci (2013) 14(9):18824-49. doi:10.3390/ijms140918824

6. Qadir J, Majid S, Khan MS, Rashid F, Wani MD, Din I, et al. AT-rich Interaction Domain 1A Gene Variations: Genetic Associations and Susceptibility to Gastric Cancer Risk. Pathol Oncol Res (2020) 26(4): 2237-46. doi:10.1007/s12253-020-00815-1

7. Mathur R, Roberts CWM. SWI/SNF (BAF) Complexes: Guardians of the Epigenome. Annu Rev Cancer Biol (2018) 2:413-27. doi:10.1146/annurevcancerbio-030617-050151

8. Jones S, Li M, Parsons DW, Zhang X, Wesseling J, Kristel P, et al. Somatic Mutations in the Chromatin Remodeling Gene ARID1A Occur in Several Tumor Types. Hum Mutat (2012) 33(1):100-3. doi:10.1002/ humu. 21633

9. Abe H, Maeda D, Hino R, Otake Y, Isogai M, Ushiku AS, et al. ARID1A Expression Loss in Gastric Cancer: Pathway-dependent Roles with and without Epstein-Barr Virus Infection and Microsatellite Instability. Virchows Arch (2012) 461:367-77. doi:10.1007/s00428-012-1303-2

10. Wang D-d., Chen Y-b., Pan K, Wang W, Chen S-p., Chen J-g., et al. Decreased Expression of the ARID1A Gene Is Associated with Poor Prognosis in Primary Gastric Cancer. PLoS One (2012) 7:e40364. doi:10.1371/journal.pone.0040364
FR, and SB; Writing—original draft: JQ and MK; Writing-review and editing: MK; Approval of final manuscript: all authors.

\section{FUNDING}

The Study was funded by the Department of Biochemistry, Govt. Medial College Srinagar and Associated Hospitals-190010.

\section{CONFLICT OF INTEREST}

The authors declare that the research was conducted in the absence of any commercial or financial relationships that could be construed as a potential conflict of interest.

\section{ACKNOWLEDGMENTS}

We are very much thankful to the study participants attending the tertiary care hospital for their cancer care.

11. Levine AJ. p53, the Cellular Gatekeeper for Growth and Division. Cell (1997) 88:323-31. doi:10.1016/s0092-8674(00)81871-1

12. Ho L, Crabtree GR. Chromatin Remodelling during Development. Nature (2010) 463:474-84. doi:10.1038/nature08911

13. Bosse T, ter Haar NT, Seeber LM, Diest PJv., Hes FJ, Vasen HF, et al. Loss of ARID1A Expression and its Relationship with PI3K-Akt Pathway Alterations, TP53 and Microsatellite Instability in Endometrial Cancer. Mod Pathol (2013) 26:1525-35. doi:10.1038/ modpathol.2013.96

14. Hanahan D, Weinberg RA. Hallmarks of Cancer: the Next Generation. Cell (2011) 144:646-74. doi:10.1016/j.cell.2011.02.013

15. Hou J, Yu Z, Xiang R, Li C, Wang L, Chen S, et al. Correlation between Infiltration of FOXP3+ Regulatory T Cells and Expression of B7-H1 in the Tumor Tissues of Gastric Cancer. Exp Mol Pathol (2014) 96:284-91. doi:10.1016/j.yexmp.2014.03.005

16. Naito T, Udagawa H, Umemura S, Sakai T, Zenke Y, Kirita K, et al. Nonsmall Cell Lung Cancer with Loss of Expression of the SWI/SNF Complex Is Associated with Aggressive Clinicopathological Features, PD-L1-Positive Status, and High Tumor Mutation burden. Lung Cancer (2019) 138:35-42. doi:10.1016/ j.lungcan.2019.10.009

17. Kim YB, Ahn JM, Bae WJ, Sung CO, Lee D. Functional Loss of ARID1A Is Tightly Associated with High PD-L1 Expression in Gastric Cancer. Int J Cancer (2019) 145:916-26. doi:10.1002/ijc.32140

18. Silva R, Gullo I, Carneiro F. The PD-1:PD-L1 Immune Inhibitory Checkpoint in Helicobacter pylori Infection and Gastric Cancer: a Comprehensive Review and Future Perspectives. Porto Biomed J (2016) 1(1):4-11. doi:10.1016/ j.pbj.2016.03.004

19. Gu L, Chen M, Guo D, Zhu H, Zhang W, Pan J, et al. PD-L1 and Gastric Cancer Prognosis: A Systematic Review and Meta-Analysis. PLoS One (2017) 12(8):e0182692. doi:10.1371/journal.pone.0182692

20. Waddell T, Chau I, Cunningham D, Gonzalez D, Okines AFC, Wotherspoon A, et al. Epirubicin, Oxaliplatin, and Capecitabine with or without Panitumumab for Patients with Previously Untreated Advanced Oesophagogastric Cancer (REAL3): a Randomised, OpenLabel Phase 3 Trial. Lancet Oncol (2013) 14:481-9. doi:10.1016/s14702045(13)70096-2

21. Liu H, Zhou M. Evaluation of P53 Gene Expression and Prognosis Characteristics in Uveal Melanoma Cases. Onco Targets Ther (2017) 10: 3429-34. doi:10.2147/ott.s136785 
22. Ito S, Masuda T, Noda M, Hu Q, Shimizu D, Kuroda Y, et al. Prognostic Significance of PD-1, PD-L1 and CD8 Gene Expression Levels in Gastric Cancer. Oncology (2020) 98(7):501-11. doi:10.1159/000506075

23. Livak KJ, Schmittgen TD. Analysis of Relative Gene Expression Data Using Real-Time Quantitative PCR and the 2- $\Delta \Delta$ CT Method. Methods (2001) 25(4): 402-8. doi:10.1006/meth.2001.1262

24. Hu N, Qian L, Hu Y, Shou J-Z, Wang C, Giffen C, et al. Quantitative RealTime RT-PCR Validation of Differential mRNA Expression of SPARC, FADD, Fascin, COL7A1, CK4, TGM3, ECM1, PPL and EVPLin Esophageal Squamous Cell Carcinoma. BMC Cancer (2006) 6:33. doi:10.1186/1471-2407-6-33

25. Nobili S, Bruno L, Landini I, Napoli C, Bechi P, Tonelli F, et al. Genomic and Genetic Alterations Influence the Progression of Gastric Cancer. World J Gastroenterol (2011) 17(3):290-9. doi:10.3748/wjg.v17.i3.290

26. Pavlidou EN, Balis V. Diagnostic Significance and Prognostic Role of the ARID1A Gene in Cancer Outcomes (Review). World Acad Sci J (2020) 2: 49-64. doi:10.3892/wasj.2020.37

27. Mamo A, Cavallone L, Tuzmen S, Chabot C, Ferrario C, Hassan S, et al. An Integrated Genomic Approach Identifies ARID1A as a Candidate TumorSuppressor Gene in Breast Cancer. Oncogene (2012) 31(16):2090-100. doi:10.1038/onc.2011.386

28. Sjöblom T, Jones S, Wood LD, Parsons DW, Lin J, Barber TD, et al. The Consensus Coding Sequences of Human Breast and Colorectal Cancers. Science (2006) 314(5797):268-74. doi:10.1126/ science. 1133427

29. Erfani M, Hosseini SV, Mokhtari M, Zamani M, Tahmasebi K, Alizadeh Naini $\mathrm{M}$, et al. Altered ARID1A Expression in Colorectal Cancer. BMC Cancer (2020) 20(1):350. doi:10.1186/s12885-020-6706-x

30. Yang Y, Wang X, Yang J, Duan J, Wu Z, Yang F, et al. Loss of ARID1A Promotes Proliferation, Migration and Invasion via the Akt Signaling Pathway in NPC. Cancer Manag Res (2019) 11:4931-46. doi:10.2147/cmar.s207329

31. Lai T, Vierkoetter K, Ayabe A, Jun Ahn H, Shimizu D, Keith YT. Ethnic Variations in ARIDla Expression in clear Cell and Endometrioid Ovarian Carcinoma. J Clin Oncol (2016) 34(15Suppl. 1):e17073. doi:10.1200/ jco.2016.34.15_suppl.e17073

32. Chan-On W, Nairismägi M-L, Ong CK, Lim WK, Dima S, Pairojkul C, et al. Exome Sequencing Identifies Distinct Mutational Patterns in Liver FlukeRelated and Non-infection-related Bile Duct Cancers. Nat Genet (2013) 45(12):1474-8. doi:10.1038/ng.2806

33. Lee SY, Kim D-W, Lee HS, Ihn MH, Oh H-K, Park DJ, et al. Loss of AT-Rich Interactive Domain 1A Expression in Gastrointestinal Malignancies. Oncology (2015) 88(4):234-40. doi:10.1159/000369140

34. Chou A, Toon CW, Clarkson A, Sioson L, Houang M, Watson N, et al. Loss of ARID1A Expression in Colorectal Carcinoma Is Strongly Associated with Mismatch Repair Deficiency. Hum Pathol (2014) 45(8):1697-703. doi:10.1016/j.humpath.2014.04.009

35. Jopling CL. Stop that Nonsense!!. eLife (2014) 3:e04300. doi:10.7554/ eLife. 04300

36. Olivier M, Hollstein M, Hainaut P. TP53 Mutations in Human Cancers: Origins, Consequences, and Clinical Use. Cold Spring Harbor Perspect Biol (2010) 2:a001008. doi:10.1101/cshperspect.a001008

37. Ogawa M, Onoda N, Maeda K, Kato Y, Nakata B, Kang S-M, et al. A Combination Analysis of P53 and P21 in Gastric Carcinoma as a strong Indicator for Prognosis. Int J Mol Med (2001) 7:479-83. doi:10.3892/ ijmm.7.5.479

38. Avery-Kiejda KA, Morten B, Wong-Brown MW, Mathe A, Scott RJ. The Relative mRNA Expression of P53 Isoforms in Breast Cancer Is Associated with Clinical Features and Outcome. Carcinogenesis (2014) 35(3):586-96. doi:10.1093/carcin/bgt411

39. Gope ML, Chun M, Gope R. Comparative Study of the Expression of Rb and P53 Genes in Human Colorectal Cancers, colon Carcinoma Cell Lines and Synchronized Human Fibroblasts. Mol Cel Biochem (1991) 107:55-63. doi:10.1007/bf02424576

40. Lothe RA, Fossli T, Danielsen HE, Stenwig AE, Nesland JM, Gallie B, et al. Molecular Genetic Studies of Tumor Suppressor Gene Regions on Chromosomes 13 and 17 in Colorectal Tumors. JNCI J Natl Cancer Inst (1992) 84:1100-8. doi:10.1093/jnci/84.14.1100
41. Takahashi R, Markovic SN, Scrable HJ. Dominant Effects of $\Delta 40 \mathrm{p} 53$ on P53 Function and Melanoma Cell Fate. J Invest Dermatol (2014) 134(3):791-800. doi:10.1038/jid.2013.391

42. Bourdon J-C, Fernandes K, Murray-Zmijewski F, Liu G, Diot A, Xirodimas DP, et al. p53 Isoforms Can Regulate P53 Transcriptional Activity. Genes Dev (2005) 19:2122-37. doi:10.1101/gad.1339905

43. Fenoglio-Preiser CM, Wang J, Stemmermann GN, Noffsinger A. TP53 and Gastric Carcinoma: a Review. Hum Mutat (2003) 21(3):258-70. doi:10.1002/ humu.10180

44. Hofstetter G, Berger A, Fiegl H, Slade N, Zorić A, Holzer B, et al. Alternative Splicing of P53 and P73: the Novel P53 Splice Variant P538 Is an Independent Prognostic Marker in Ovarian Cancer. Oncogene (2010) 29:1997-2004. doi:10.1038/onc.2009.482

45. Ioachim E, Goussia A, Stefanou D, Agnantis NJ. Expression of P53 Protein in Gastric Cancer: an Immunohistochemical Study with Correlation to Proliferative Activity. Anticancer Res (1997) 17:513-7.

46. Sasaki I, Yao T, Nawata H, Tsuneyoshi M. Minute Gastric Carcinoma of Differentiated Type with Special Reference to the Significance of Intestinal Metaplasia, Proliferative Zone, and P53 Protein during Tumor Development. Cancer (1999) 85:1719-29. doi:10.1002/(sici)1097-0142(19990415)85:8<1719: aid-cncr11>3.0.co;2-v

47. Kakeji Y, Korenaga D, Tsujitani S, Baba H, Anai H, Maehara Y, et al. Gastric Cancer with P53 Overexpression Has High Potential for Metastasising to Lymph Nodes. Br J Cancer (1993) 67:589-93. doi:10.1038/bjc.1993.108

48. Mönig SP, Eidt S, Zirbes TK, Stippel D, Baldus SE, Pichlmaier H. p53 Expression in Gastric Cancer: Clinicopathological Correlation and Prognostic Significance. Dig Dis Sci (1997) 42:2463-7. doi:10.1023/a: 1018844008068

49. El-Mahdani N, Vaillant J-C, Guiguet M, Prévot S, Bertrand V, Bernard C, et al. Overexpression of P53 mRNA in Colorectal Cancer and its Relationship to P53 Gene Mutation. Br J Cancer (1997) 75(4):528-36. doi:10.1038/bjc.1997.92

50. Mühlmann G, Öfner D, Zitt M, Müller HM, Maier H, Moser P, et al. 14-3-3 Sigma and P53 Expression in Gastric Cancer and its Clinical Applications. Dis Markers (2010) 29(1):21-9. doi:10.1155/2010/470314

51. Carneiro F, David L, Sobrinho-Simoes M, Seruca R, Nesland JM. Oncogene S and Onco-Suppressor Genes in Gastric Cancer Carcinoma. Surg Pathol (1994) 5(3):225-38.

52. Haronikova L, Olivares-Illana V, Wang L, Karakostis K, Chen S, Fahraeus R. The P53 mRNA: an Integral Part of the Cellular Stress Response. Nucleic Acids Res (2019) 47(7):3257-71. doi:10.1093/nar/gkz124

53. Shiao YH, Rugge M, Correa P, Lehmann HP, Scheer WD. p53 Alteration in Gastric Precancerous Lesions. Am J Pathol (1994) 144:511-7.

54. Misiewicz JJ. The Sydney System: A New Classification of Gastritis. Introduction. J Gastroenterol Hepatol (1991) 6(3):207-8. doi:10.1111/j.14401746.1991.tb01467.x

55. Morales-Fuentes GA, Zarate-Osorno A, Quiñónez-Urrego EE, AntonioManrique M, Martínez-García CL, Figueroa-Barojas P, et al. p53 expresado en la mucosa gástrica de pacientes infectados por Helicobacter pylori. Rev Gastroenterol Méx (2013) 78(1):12-20. doi:10.1016/j.rgmx.2012.11.001

56. Wei J, Nagy TA, Vilgelm A, Zaika E, Ogden SR, Romero-Gallo J, et al. Regulation of P53 Tumor Suppressor by Helicobacter pylori in Gastric Epithelial Cells. Gastroenterology (2010) 139:1333-43. doi:10.1053/ j.gastro.2010.06.018

57. Ahmed A, Smoot D, Littleton G, Tackey R, Walters CS, Kashanchi F, et al. Helicobacter pylori Inhibits Gastric Cell Cycle Progression. Microbes Infect (2000) 2:1159-69. doi:10.1016/s1286-4579(00)01270-3

58. Wu C, Zhu Y, Jiang J, Zhao J, Zhang X-G, Xu N. Immunohistochemical Localization of Programmed Death-1 Ligand-1 (PD-L1) in Gastric Carcinoma and its Clinical Significance. Acta Histochem (2006) 108:19-24. doi:10.1016/ j.acthis.2006.01.003

59. Sun J, Xu K, Wu C, Wang Y, Hu Y, Zhu Y, et al. PD-L1 Expression Analysis in Gastric Carcinoma Tissue and Blocking of Tumor-Associated PD-L1 Signaling by Two Functional Monoclonal Antibodies. Tissue Antigens (2007) 69:19-27. doi:10.1111/j.1399-0039.2006.00701.x 
60. Chen XL, Cao XD, Kang AJ, Wang KM, Su BS, Wang YL. In Situ expression and Significance of B7 Costimulatory Molecules within Tissues of Human Gastric Carcinoma. World J Gastroenterol (2003) 9:1370-3. doi:10.3748/wjg.v9.16.1370

61. Afreen S, Dermime S. The Immunoinhibitory B7-H1 Molecule as a Potential Target in Cancer: Killing many Birds with One Stone. Hematol Oncol Stem Cel Ther (2014) 7:1-17. doi:10.1016/j.hemonc.2013.09.005

62. Cortez MA, Ivan C, Valdecanas D, Wang X, Peltier HJ, Ye Y, et al. PDL1 Regulation by P53 via miR-34. J Natl Cancer Inst (2016) 108(1):djv303. doi:10.1093/jnci/djv303

63. Cha YJ, Kim HR, Lee CY, Cho BC, Shim HS. Clinicopathological and Prognostic Significance of Programmed Cell Death Ligand-1 Expression in Lung Adenocarcinoma and its Relationship with P53 Status. Lung Cancer (2016) 97:73-80. doi:10.1016/j.lungcan.2016.05.001

64. Tojyo I, Shintani Y, Nakanishi T, Okamoto K, Hiraishi Y, Fujita S, et al. PD-L1 Expression Correlated with P53 Expression in Oral Squamous Cell Carcinoma.
Maxillofac Plast Reconstr Surg (2019) 41(1):56. doi:10.1186/s40902-0190239-8

65. Chang T-C, Wentzel EA, Kent OA, Ramachandran K, Mullendore M, Lee KH, et al. Transactivation of miR-34a by P53 Broadly Influences Gene Expression and Promotes Apoptosis. Mol Cel (2007) 26:745-52. doi:10.1016/ j.molcel.2007.05.010

Copyright (c) 2021 Qadir, Majid, Khan, Rashid, Wani and Bhat. This is an openaccess article distributed under the terms of the Creative Commons Attribution License (CC BY). The use, distribution or reproduction in other forums is permitted, provided the original author(s) and the copyright owner(s) are credited and that the original publication in this journal is cited, in accordance with accepted academic practice. No use, distribution or reproduction is permitted which does not comply with these terms. 